\title{
Differences in the patterns of distribution of the porcelain crab, Petrolisthes japonicus on an oceanic island (Chichijima, Ogasawara) and on a continental island (Zamami, Okinawa).
}

\author{
Akira Asakura \\ Natural History Museum and Institute, Chiba \\ 955-2, Aoba-cho, Chiba-shi, 280 JAPAN \\ イソカニダマシの小笠原と沖縄における分布パターンの違い \\ 朝 倉彰 \\ 千葉県立中央博物館
}

\begin{abstract}
Distribution pattern of the porcelain crab, Petrolisthes japonicus found in the intertidal boulder beaches of an oceanic island, Chichijima, Ogasawara (Bonin) was compared with that in a continental island, Zamami, Okinawa (Ryukyu). P. japonicus occupied widely over the entire intertidal boulder beaches in Ogasawara, where only one species of the porcelain crab inhabits. In Okinawa, however, P. japonicus was restricted in the middle intertidal zone and its habitat was significantly narrower and higher than those on Chichijima. In Okinawa, six other species of porcelain crabs, $P$. hastatus, $P$. lamarckii, $P$. fimbriatus, $P$. tomentosus, $P$. carinipes and $P$. asiaticus coexisted there, and the distribution patterns of them can be clearly divided into two types: the middle intertidal type, ( $P$. japonicus and $P$. hastatus) and the lower intertidal type ( $P$. asiaticus, $P$. tomentosus, P. lamarckii, P. fimbriatus and P. carinipes.
\end{abstract}

\section{Introduction}

Although Okinawa (Ryukyu) and Ogasawara (Bonin) are situated at nearly the same latitude $\left(27^{\circ} \mathrm{N}\right)$ and have nearly the same marine climate in terms of sea water temperature and its seasonal changes (KuRATA et al., 1975), there is a large difference between the characteristics of the fauna in the two groups of islands. Okinawa has a rich marine fauna, which is brought by the Kuroshio Current from areas with extremely diverse fauna in the west tropical Pacific (ЕкмаN, 1956; Briggs, 1978, 1987). By contrast, Ogasawara is a group of isolated oceanic islands, with the nearest landmass being the main islands of Japan, $1000 \mathrm{~km}$ away, and, as a result, is associated with limited variety of terrestrial as well as marine fauna (HABE et al., 1978; OoIsHI, 1970).

Although, to date, several marine biological surveys have been conducted in Oga- 
sawara (See ElDREDGE, 1977, for review), they focused predominantly on taxonomy. Only a few ecological studies have been reported (e.g., Asakura and Nishinama, 1987; ASAKURA et al., 1990) and more are needed to clarify the characteristics of these isolated oceanic islands.

The porcelain crab, Petrolisthes japonicus, is common on the intertidal boulder beaches of the temperate and tropical waters of Japan (Мгу аке, 1982). This short paper reports the differences in patterns of distribution of P. japonicus in Okinawa and Ogasawara, in relation to other species of porcelain crabs that coexist in the same habitat.

\section{Study sites, Materials, and Methods}

A moderately wave-exposed boulder beach of Zamami Island in Okinawa and two such beaches of Chichijima Island in Ogasawara were selected for the study (Fig.1). Zamami and Chichijima are separated by about $2000 \mathrm{~km}$ from each other. Zamami has a well-developed coral reef, its beaches are made of raised limestone and calcareous rocks, and calcareous white sand is deposited among and under boulders. Whereas the beaches of Chichijima are constructed entirely of volcanic substrata, and black, volcanic sand is deposited. At each site, slope is gentle whole a beach and boulders are less than $50 \mathrm{~cm}$ in diameter, so no drastic change in environmental condition is seen from upper to lower intertidal zone besides one derived from the tidal level difference.

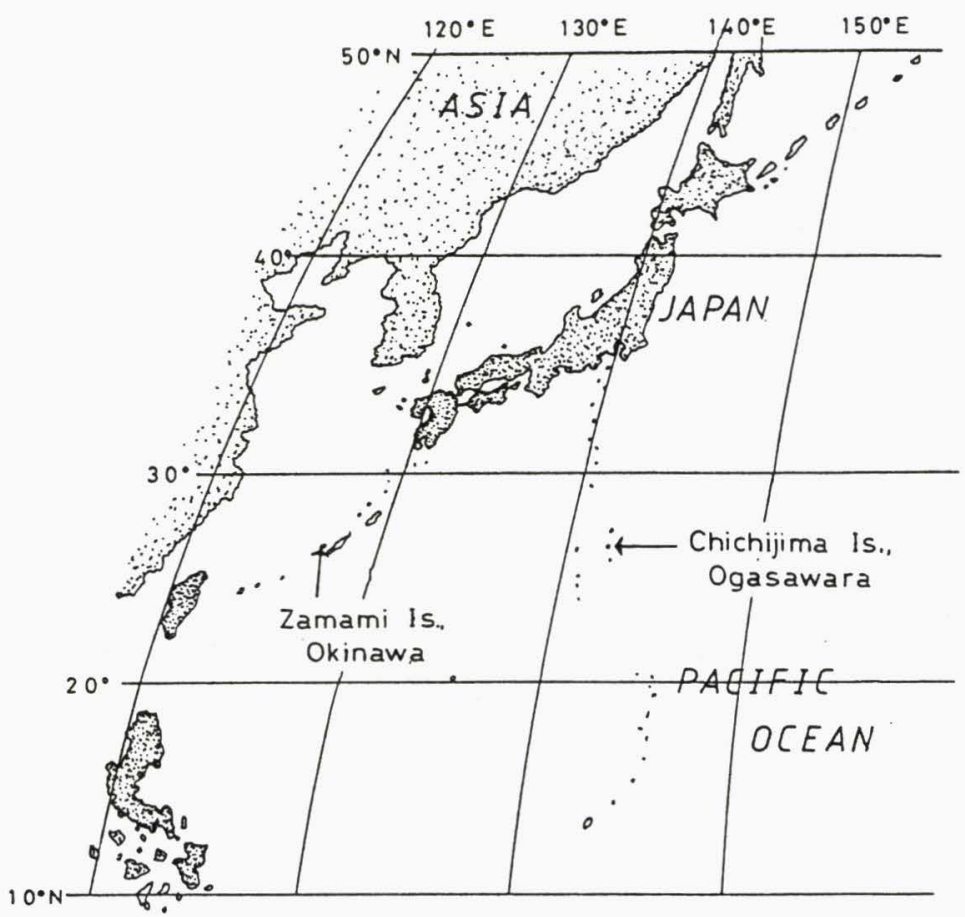


In each locality, the topographical profile of the intertidal area was recorded, and a quadrat $(1 \mathrm{~m} \times 1 \mathrm{~m})$ was set up at 5 or 6 points from the upper to the lower intertidal zone. Animals in the quadrat were collected, and porcelain crabs were identified to species. For reference, other decapods were also collected and identified to the family level. These procedures were done in April 1986 in Chichijima and in March 1987 in Zamami.

For each species, the mean position and the extent of the habitat are represented by the mean value of the relative vertical height of the distribution and its standard deviation, respectively. These were presented on the assumption that the level of extreme high-water of spring tide at a given site was 100 and the level of the low-water of spring tide was 0 . Mean tidal ampulitude is $1.10 \mathrm{~m}$ in Ogasawara and $2.30 \mathrm{~m}$ in Okinawa.

\section{Results}

In Ogasawara, only one species of the porcelain crab, $P$. japonicus, was collected. Their habitat widely extended whole the boulder beaches in both sites (range of distri-

Table 1. Position and extent of the habitat of each species in the intertidal zone. Mean relative values of height are representative of habitat position, and the standard deviations are representative of the extent of the habitat. Ch: Chichijima (Ogasawara), Ok: Okinawa, P.: Petrolisthes. See also Table 2 for a, b and c.

\begin{tabular}{|c|c|c|c|}
\hline \multirow[b]{2}{*}{ locality /species } & \multirow[b]{2}{*}{$\mathrm{n}$} & \multicolumn{2}{|c|}{ habitat } \\
\hline & & mean height & spread (s.d.) \\
\hline \multicolumn{4}{|l|}{ Okumura (Ch) } \\
\hline P. japonicus & 367 & 21.5 & $17.1^{\mathrm{a}}$ \\
\hline Grapsidae spp. & 13 & 27.5 & 13.1 \\
\hline Xanthidae spp. & 8 & 23.0 & 17.9 \\
\hline \multicolumn{4}{|l|}{ Sakaiura (Ch) } \\
\hline P. japonicus & 43 & 20.9 & $13.3^{\mathrm{b}}$ \\
\hline Grapsidae spp. & 27 & 29.7 & 15.4 \\
\hline Xanthidae spp. & 4 & 30.5 & 14.8 \\
\hline \multicolumn{4}{|l|}{ Zamami (Ok) } \\
\hline P. japonicus & 374 & 36.7 & $8.6^{\mathrm{c}}$ \\
\hline P. hastatus & 564 & 33.2 & 8.1 \\
\hline$P$ lamarckii & 22 & 4.7 & 8.0 \\
\hline P. fimbriatus & 35 & 4.7 & 7.3 \\
\hline P. tomentosus & 20 & 8.8 & 7.8 \\
\hline P. carinipes & 4 & 11.2 & 6.4 \\
\hline P. asiaticus & 3 & 10.7 & 8.2 \\
\hline Portunidae spp. & 66 & 15.4 & 12.3 \\
\hline Xanthidae spp. & 36 & 17.0 & 14.3 \\
\hline Dromiidae spp. & 3 & 0.0 & 0.0 \\
\hline Grapsidae spp. & 12 & 44.8 & 3.9 \\
\hline
\end{tabular}


Table 2. Comparison of habitat of P. japonicus. a: Okumura population in Chichijima, b: Sakaiura population in Chichijima, c: Zamami population. See also Table 1 for data of $\mathrm{a}, \mathrm{b}$, and $\mathrm{c}$.

\begin{tabular}{ccccc}
\hline \multicolumn{2}{l}{ Spread difference (ANOVA) } & & & \\
\hline combination & Fcal & df1 & df2 & p \\
\hline a-c & 3.93 & 365 & 373 & $<0.001$ \\
b-c & 2.37 & 42 & 373 & $<0.001$ \\
\hline Height difference (Aspin-Welsh's t-test) & & & \\
\hline combination & tcal & AW's N & & p \\
\hline a-c & 15.21 & 539 & & $<0.001$ \\
b-c & 7.61 & 46 & & $<0.001$ \\
\hline \hline
\end{tabular}

bution of animals $=38.2-0$, that of boulders $=40.0-0$ in Okumura; range of distribution of animals $=44.1-0$, that of boulders $=45.0-0$ in Sakaiura; see also Table 1). Brachyuran crabs of Grapsidae and Xanthidae were also collected at low density from the middle to lower intertidal zones (Table 1), and there is no significant correlation of distribution between the brachyuran crabs and P. japonicus ( $\mathrm{p}>0.2$, Kendall's $\tau$-test).

In Okinawa, 7 species of Petrolisthes and brachyuran crabs belonging to the Portunidae, Xanthidae, Dromiidae, and Grapsidae were collected (Table 1). The habitat of $P$. japonicus was restricted (range of distribution of the animals $=41.4-14.28$, that of boulders $=42.0-0$ ) and significantly narrower and higher than those on Chichijima (Table 2). The distribution patterns of the porcelain crabs can be clearly divided into two types (Table 1): the middle intertidal type (P. japonicus and P. hastatus) and the lower intertidal type ( $P$. asiaticus, $P$. tomentosus, P.lamarckii, P. fimbriatus, and $P$. carinipes). The distribution of $P$. hastatus shows a significant positive correlation with that of $P$. japonicus ( $\tau=0.60, \mathrm{p}<0.05$, KendalL's $\tau$-test). Whereas the distributions of the lower intertidal type were significantly lower than that of $P$. japonicus $(\tau=-0.60,-0.73,-$ $0.67,-0.80,-0.60$, for above-mentioned species, respectively; $\mathrm{p}<0.05$ in all cases; Kendall's $\tau$-test). Grapsids of brachyran crabs were found middle intertidal, and dromiids were found lower intertidal, though their distributions were not significantly correlated with the distribution of P. japonicus. Xanthids and portunids were mainly found in the lower intertidal area, and their distributions were significant negatively correlated with that of $P$. japonicus ( $\tau=-0.87,-0.67 ; \mathrm{p}<0.05$ in both cases; KendaLL's $\tau$-test).

\section{Discussion}

Why P. japonicus on Ogasawara has a wider habitat than it has on Okinawa is 
questionable, but one possible answer may be difference in number of species occurred in each place.

Since all the Petrolisthes spp. collected in this study inhabit the underside of boulders, competition for habitat is to be expected. In Chichijima, as only one species, P. japonicus, inhabits the beaches, these crabs are able to distribute themselves over the entire boulder beach (to date, only one species of Petrolisthes ( $P$. japonicus) has been recorded from Chichijima (Oıshi, 1970; Mrуaкe, 1982). In temperate waters of Japan, P. japonicus also inhabits whole a intertidal zone, where other species of porcelain crabs rarely occur (Asakura unpubl.; Miyake, 1982). In Zamami, however, seven species of porcelain crabs coexist, a situation that would be expected to result in a more limited distribution of each species, as, in fact, turns out to be the case. To date, 11 Petrolisthes spp. have been recorded from the Okinawa-jima Island, $30 \mathrm{~km}$ west of Zamami (Mıу AкE, 1982).

A similar example is seen in a trochid snail, Monodonta perplexa. M. perplexa boninensis in Ogasawara is widely distributed over the middle to lower intertidal pebble beaches, where two species of trochids inhabit, even though $M$. perplexa perplexa on the main islands of Japan is restricted to middle intertidal pebble beaches, where four species of trochids coexists (Asakura and Nishinama, 1987).

It is often reported that an increase in the number of species using the same resource results in a decrease in the availability of that resource to each species (MacArTHUR, 1972). This phenomenon is evident when animals on a continental island and on an oceanic island are compared (MacArthur and Wilson, 1967; Williamson, 1981).

However, in this study, another question arises: why do the two most abundant species, $P$. japonicus and $P$. hastatus, occupy nearly the same position? If they use the underside of boulders efficiently, they should occupy separate habitats.

On other possibilities, further study is clearly needed of the factors that affect their distribution, for example, predation, environmental factors, physical disturbances and so on, in each zone. The distribution of predatory portunid crabs in the lower intertidal zone may influence the distribution of porcelain crabs.

\section{Acknowledgments:}

The author deeply thanks Messers Shirou Nishinama and Raymond Kiyoshi NaKAMURA of Amakusa Marine Biological Laboratory, Kyushu University, for their aids in the field work, and also thanks Dr. A.M. KorNer for improving English.

\section{References}

Asakura, A., Y. Kondo, W. Sato-Oкоsнi, and M. Miyata. 1990. Distribution of animals and plants on the rocky shores of Hahajima in the Ogasawara Islands. Nat. Hist. Res., (Bull. Nat. Hist. Mus. Inst., Chiba) 1: 65-79.

Asakura, A. and S. Nishinama. 1987. Studies on the biology and ecology of the intertidal animals of 
Chichijima Island in the Ogasawara (Bonin) Islands-III. Description, form and habitat of the trochid snail, Monodonta perplexa boninensis n. subsp. in comparison with those in Monodonta perplexa perplexa (Pilsbry). Venus, Jap. Jour. Malac. 46: 194-201.

BRIGGS, J.C. 1978. Marine Zoogeography. McGraw-Hill, New York, 475 pp.

Briggs, J.C. 1987. Biogeography and Plate Tectonics. Elsevier, Amsterdam, 204 pp.

Екмал, S. 1956. Zoogeography of the Sea. Sidwick and Jackson Ltd. London, 417 pp.

EldRedge, L.G. 1977. Biological research in the Bonin Islands. Atoll Res. Bull. 185: 34-37

Habe, T., T. Akazawa, I. Fujiyama, Y. Kuwano, H. Morioka, T. Nakaike, M. Takeda, M. Watanabe, and B. Yamaguchi. 1978. The natural history research of the Izu-Mariana Arc. Bull. Nat. Sci. Mus. 11: $1-10$.

Kurata, Y., M. Tsusumi, M. Kolzumi, and S. Yoneyama. 1975. Marine organisms of the Ogasawara Island: Report on the basic survey about fishery development of the Ogasawara Islands. Publ. Ogasawara Fish. Cent. 2: 93-134.

MacArthuR, R.H. 1972. Geographical Ecology- Patterns in the Distribution of Species. Harper and Row, New York, 269 pp.

MacArthuR, R.H. and E.O. WiLson. 1967. The Theory of Island Biogeography. Princeton Univ Press, New Jersey, $203 \mathrm{pp}$.

Miy AKE, S. 1982. Japanese crustacean decapods and stomatopods in color-I. Macrura, Anomura and Stomatopoda. Hoikusha, Osaka, 261 pp. +56 pls.

OoIsHI, S. 1970. Marine invertebrate fauna of the Ogasawara and Volcano Islands collected by S. Oishi, Y. Tomida, K. Izawa and S. Matabe. pp.75-104. In: Report on the Marine Biological Expedition to the Ogasawara (Bonin) Islands, 1968. Toba Aquarium and Asahi Shinbun Publ. Comp., Mie,

Williamson, M. 1981. Island Populations. Oxford Univ Press, Oxford, 286 pp.

摘要

転石海岸潮間帯に生息するイソカニダマシの分布パターンを，小笠原諸島父島と，沖縄慶良 間諸島座間味島とで比較した。父島の奥村と境浦の転石海岸に生息するカニダマシ類はイソカ ニダマシ 1 種類のみで, 海岸の全体に分布していた。一方沖縄の座間味島では, 7 種類のカ二 ダマシ類が同所的に分布し, イソカニダマシとミナミカニダマシは転石海岸の中部を中心に, またアジアアカハラ・ケブカカニダマシ・ヒロバカニダマシ・ヨロンカニダマシ・ケハダカニ ダマシは転石海岸の下部を中心に分布していた。従って相対的にイソカニダマシの分布域は沖 縄で狭く,より高い位置にあった。 